J. Product. \& Dev., 16(3):369-377(2011)

\title{
PERFORMANCE OF SOME RICE CULTIVARS AS AFFECTED BY NITROGEN FERTILIZER SOURCES UNDER SALINE SOIL IN NORTH DELTA
}

\author{
A. E. Sharief* and A.A. Hassan** \\ *Agron. Department, Faculty of Agriculture, Mansoura University, Mansoura, \\ Egypt. \\ ** Institute of Efficient Productivity, Zagazig University, Zagazig, Egypt.
}

\section{ABSTRACT}

Two field experiments were conducted under salt affected soil at ElSirw Agriculture Research Station Farm, Damietta, Egypt, during 2008 and 2009 growing seasons through rice salinity program to study the performance of three rice cultivars namely, Giza 178 Sakha 101 and Sakha 102 under three sources of nitrogen fertilizer (urea, ammonium sulphate and ammonium nitrate).The Ec and the $\mathrm{pH}$ of the experimental site were $10.2 \mathrm{ds} / \mathrm{m}^{2}$ and 7.8 , respectively. A strip plot design with four replications was used. The main finding could be summarized as follows:

The results revealed that Giza 178 cultivar had higher sink capacity, sink size and grain straw ratio than-the other tested cultivars. Giza 178 cultivar surpassed Sakha 101 and Skha 102 cultivars in number of panicles $/ m^{2}$, number of grains/panicle as well as grain and straw yields (t/ha) in saline soils.

Application of nitrogen in the form of urea or ammonium sulphate were more efficient for rice than ammonium nitrate in saline soil which increased agronomic efficiency of nitrogen fertilizer and hence increase number of panicles/ $\mathrm{m}^{2}$, number of filled grains / panicle, grain and straw yields / ha.

It could be concluded that maximum grain yield was obtained from planting Giza 178 cultivar and using urea or ammonium sulphate as a good sources of nitrogen under saline soil in North Delta.

Key words: Rice performance, cultivars, nitrogen fertilizer sources, saline soil, North Delta 


\section{INTRODUCTION}

Improving salt tolerant rice to be grown in salt-affected areas could be considered as one of the ways to increase their level of production. Rice is reported as very sensitive (De Datta, 1972) to moderately (Mass and Hoffman, 1977) to salinity. Rice cultivars significantly differed in their grain yield and its attributes under salt affected conditions (Zeidan et al., 1980, Rahman 1985 and Abd El-Rahman et al., 1988).

Also nitrogen sources could be affected rice productivity under salt affected area. De Datta et al. (1974) found that grain yield of rice responded to either ammonium sulphate or urea. Saares et al. (1983) reported that number of tillers $/ \mathrm{m}^{2}$, number of panicles $/ \mathrm{m}^{2}$, number of grains/panicle and 100 -grain weight were higher when rice fertilized by urea or ammonium sulphate. Meelu et al. (1987) pointed out that the calcium ammonium nitrate was significantly inferior to urea and ammonium sulphate for rice.

Concerning the interaction between rice cultivars and nitrogen fertilizer sources, Kumar and Kandaswamy (1984) studied the response of rice variety IR 20 to four sources of nitrogen (ammonium sulphate, calcium ammonium nitrate, diammonium phosphate or urea), they found that highest grain yield was recorded when ammonium sulphate was applied. Koriem et al. (1992) studied the response of rice variety IR 20 to three nitrogen forms (ammonium sulphate, urea and ammonium nitrate). The data indicated that the yield and yield components were significantly affected by the three nitrogen forms used. Ling and Yang (1986) showed that sink capacity (number of spikelets per unit field area), sink size (weight of panicles per unit field area) were higher when medium and short duration cultivars fertilized by urea or ammonium sulphate as a source of nitrogen.

Therefore, the present investigation was aimed to study the performance of some rice cultivars to nitrogen fertilizer sources under salt-affected area of North Delta.

\section{MATERIALS AND METHODS}

Two field experiments were conducted in the two successive seasons of 2008 and 2009 under saline soil conditions at El-Serw Agriculture Research Station Farm, Damietta, Egypt. This investigation was carried out in order to study the response of three rice cultivars, namely Giza 178, Sakha 101 and Sakha 102 to three sources of nitrogen fertilizer i.e. urea $(46 \% \mathrm{~N})$, ammonium sulphate $(20.5 \% \mathrm{~N})$ and ammonium nitrate $(33.5 \% \mathrm{~N})$ The differences between studied cultivars could be summarized as shown in Table 1. A strip plot design 
with four replications was used. Cultivars were randomly arranged in the horizontal plots. While the vertical plots received the three nitrogen fertilizer sources. The plots size was $15 \mathrm{~m}(3 \mathrm{X} 5 \mathrm{~m})$ i.e. $1 / 280$ fed. Cultivars were transplanted at heavy clay soil in rows $20 \mathrm{~cm}$ apart and hills $20 \mathrm{~cm}$ apart. Mechanical and chemical analysis of the experimental soil are presented in Table 2 as described by Page et a/(1982) method. The preceding crop in both seasons was barley. Calcium superphosphate at a rate of $250 \mathrm{Kg} / \mathrm{ha}\left(15.5 \% \mathrm{P}_{2} \mathrm{O}_{5}\right)$ were incorporated during land preparation. Nitrogen at the rate of $96 \mathrm{kgN} / \mathrm{ha}$ was applied in two equal doses, $1 / 2$ at 20 days after transplanting and the rest after 30 days from the first dose. The other cultural practices were applied following the recommendation for transplanted rice.

At harvest, ten guarded hills were taken for estimating the following characters:

1.Plant height $(\mathrm{cm})$.

2.Number of tillers/hill.

3.Panicle length $(\mathrm{cm})$.

4.Number of filled grains/panicle.

5.1000-grain weight (g).

In addition, one square meter of each experimental unit were harvested and collected together for counting number of panicles $/ \mathrm{m}^{2}$. Sink capacity as number of spikelets/unit area $\left(1 \mathrm{~m}^{2}\right)$ and sink size (weight of panicles/unit area) were determined according to Ling and Yong, 1986.

Table 1:Rice cultivars used and its characters

\begin{tabular}{lccc}
\hline Characters & Sakha 101 & Sakha 102 & Giza 178 \\
\hline 1- Crosses & Giza 176/Milyang79 & Giza $177 / \mathrm{C}_{24} 096-7-\mathrm{i}$ & Giza 176/Milyang \\
2-Tillering capacity & High & Low & High \\
3- Salt sensitivity & Moderately tolerant & Sensitive & Tolerant \\
4-Drought sensitivity & $=$ & $=$ & $=$ \\
5-Duration & $130-135$ days & $120-125$ days & $130-135$ days \\
6- Type & Japonica & Japonica & Japonica X Indica \\
\hline
\end{tabular}

Agronomic efficiency of fertilizer was estimated as $\mathrm{kg}$ rice/ $\mathrm{kg} \mathrm{N}$ applied according to Yoshida et al. (1972). At harvest, plants in the six square meter of each experimental unit were harvested, labeled and transported to the threshing area for air-drying. Five days later the plants were threshed and the grain weight was recorded at $14 \%$ moisture content. Grain and straw yields were recorded and expressed in ton/hectare. 
Table 2: Mechanical and chemical analysis of the experimental soil during the two seasons.

\begin{tabular}{|c|c|c|c|c|c|c|c|c|c|c|c|}
\hline \multirow[t]{3}{*}{ Seasons } & \multicolumn{3}{|c|}{ Mechanical analysis } & \multicolumn{7}{|c|}{ Chemical analysis } & \multirow[t]{3}{*}{ PH } \\
\hline & \multirow[t]{2}{*}{ Silt\% } & \multirow[t]{2}{*}{ Clay \% } & \multirow[t]{2}{*}{ Soil } & \multicolumn{3}{|c|}{$\begin{array}{c}\text { Avilable } \\
\text { macronutrients } \\
\text { (PPM) } \\
\end{array}$} & \multirow[t]{2}{*}{$\begin{array}{c}\text { Ece } \\
\mathbf{d s} / \mathbf{m}^{2}\end{array}$} & \multirow[t]{2}{*}{$\begin{array}{c}\mathrm{Na} \\
\mathrm{Meq} / 1\end{array}$} & \multirow[t]{2}{*}{$\begin{array}{c}\mathrm{co}_{3^{-}} \\
\mathrm{Meq} / \mathrm{I}\end{array}$} & \multirow[t]{2}{*}{$\begin{array}{c}\text { SOT } \\
\text { Meq/I }\end{array}$} & \\
\hline & & & & $\mathbf{N}$ & $\mathbf{P}$ & $\mathbf{K}$ & & & & & \\
\hline 2008 & 24.17 & 75.62 & $\begin{array}{l}\text { Heavy } \\
\text { Clay }\end{array}$ & 19.9 & 20.4 & 219 & 9.2 & 49 & 1.1 & 31 & 7.8 \\
\hline 2009 & 22.63 & 76.57 & $\begin{array}{c}\text { Heavy } \\
\text { Clay }\end{array}$ & 20.1 & 19.8 & 225 & 9.8 & 51 & 1.2 & 33 & 7.9 \\
\hline
\end{tabular}

The obtained data were subjected to the proper statistical analysis of variance and combined analysis was performed along the two seasons. The differences among averages of the studied traits were judged with the Least Significant Differences (LSD) at $5 \%$ level of significantly described by Gomez and Gomez (1984).

\section{RESULTS AND DISCUSSION}

\section{Varietal performance:}

The three tested cultivars significantly differed concerning plant height (cm) number of tillers $/$ hill, number of panicles $/ \mathrm{m}^{2}$, number of filled grains/panicle, 1000-grain weight (g) and grain yield (t/ha) as well as straw yield (t/ha) in both seasons and panicle length in the second season as presented in Tables 3 and 4. Giza 178 rice cultivar produced the highest number of panicles/ $\mathrm{m}^{2}$ (450) and number of filled grains/panicle (145.5) which resulted in highest grain yield $(7.303 \mathrm{t} / \mathrm{ha})$ as well as straw yield $(8.037 \mathrm{t} / \mathrm{ha})$ over both seasons. Sakha 102 rice cultivar showed its superiority only in plant height $(98.3 \mathrm{~cm})$ and its inferiority in number of panicles/ $\mathrm{m}^{2}$ (391) as well as number of filled grains/panicle (113.1) over both seasons. Where as, Sakha 101 cultivar produced the same 1000-grain weight (27.93 g), as well as, grain and straw yields as those produced by Sakha 102 cultivar as averages of both seasons.

Yield potential of cultivars is determined not only by sufficient source of photosynthetic, but also by sink capacity and size of spikelets for receiving photosynthetic from the leaves. So, the improvement in sink capacity and size are necessary for increasing yield of rice (Yoshida, 1983). Sink capacity (number of spikelets/unit field area) and sink size (weight of panicles/unit field area) of Giza 178 cultivar were higher followed by Sakha 101 cultivar, while Sakha 102 cultivar gave the lowest values in these respects as shown in Table 4. 
Table 3: Means of plant height, number of tillers/hill, panicle length, number of panicles $/ \mathrm{m}^{2}, 1000$-grain weight and number of filled grains/panicle as affected by rice cultivars performance and nitrogen sources during both seasons.

\begin{tabular}{|c|c|c|c|c|c|c|c|c|c|c|c|c|c|}
\hline \multirow{2}{*}{\multicolumn{2}{|c|}{ Treatments }} & \multicolumn{2}{|c|}{$\begin{array}{l}\text { Plant height } \\
\quad(\mathrm{cm})\end{array}$} & \multicolumn{2}{|c|}{$\begin{array}{l}\text { No. of } \\
\text { tillers/hill }\end{array}$} & \multicolumn{2}{|c|}{$\begin{array}{c}\text { Panicle } \\
\text { length } \\
(\mathrm{cm})\end{array}$} & \multicolumn{2}{|c|}{$\begin{array}{c}\text { No. of } \\
\text { Panicles } / \mathbf{m}^{2}\end{array}$} & \multicolumn{2}{|c|}{$\begin{array}{l}\text { 1000-grain } \\
\text { weight (g) }\end{array}$} & \multicolumn{2}{|c|}{$\begin{array}{c}\text { No. of filled } \\
\text { grains/panicle }\end{array}$} \\
\hline & & 2008 & 2009 & 2008 & 2009 & 2008 & 2009 & 2008 & 2009 & 2008 & 2009 & 2008 & 2009 \\
\hline & & \multicolumn{12}{|c|}{ Cultivars: } \\
\hline \multicolumn{2}{|c|}{ Giza 178} & 89.5 & 89.0 & 20.4 & 20.1 & 21.8 & 21.7 & 460 & 448 & 20.66 & 20.53 & 148.7 & 142.4 \\
\hline \multicolumn{2}{|c|}{ Sakha 101} & 82.7 & 80.8 & 18.4 & 16.9 & 21.4 & 21.1 & 402 & 403 & 28.13 & 27.73 & 119.9 & 117.1 \\
\hline \multicolumn{2}{|c|}{ Sakha 102} & 99.3 & 97.2 & 18.0 & 19.1 & 21.3 & 21.0 & 388 & 395 & 28.26 & 28.00 & 113.9 & 112.4 \\
\hline \multicolumn{2}{|c|}{ F. test } & $* *$ & $* *$ & $* *$ & $* *$ & NS & $* *$ & $* *$ & $* *$ & $* *$ & $* *$ & $* *$ & $* *$ \\
\hline LSD & $5 \%$ & 3.9 & 1.2 & 1.8 & 0.4 & - & 0.3 & 12 & 13 & 0.25 & 0.46 & 2.8 & 1.7 \\
\hline \multirow[t]{2}{*}{ LSD } & $1 \%$ & 5.7 & 1.7 & 2.7 & 0.7 & - & 0.4 & 18 & 19 & 0.37 & 0.67 & 4.1 & 2.5 \\
\hline & & \multicolumn{12}{|c|}{ Nitrogen sources } \\
\hline \multicolumn{2}{|l|}{ Urea } & 90.5 & 88.1 & 18.3 & 19.2 & 21.4 & 21.3 & 422 & 427 & 25.60 & 25.70 & 128.5 & 126.6 \\
\hline \multirow{2}{*}{\multicolumn{2}{|c|}{$\begin{array}{l}\text { Ammoniu } \\
\text { m sulphate } \\
\text { Ammoniu } \\
\text { m nitrate }\end{array}$}} & 90.4 & 90.0 & 19.5 & 18.6 & 21.6 & 21.3 & 422 & 415 & 26.00 & 25.50 & 128.8 & 124.4 \\
\hline & & 90.6 & 88.9 & 18.9 & 18.4 & 21.4 & 21.0 & 405 & 398 & 25.40 & 25.00 & 125.2 & 120.9 \\
\hline \multicolumn{2}{|c|}{ F. test } & NS & NS & NS & NS & NS & NS & $* *$ & $* *$ & $* *$ & $*$ & $* *$ & $* *$ \\
\hline LSD & $5 \%$ & - & - & - & - & - & - & 10 & 13 & 0.36 & 0.25 & 2.2 & 1.4 \\
\hline LSD & $1 \%$ & - & - & - & - & - & - & 15 & 18 & 0.55 & - & 3.2 & 2.0 \\
\hline \multicolumn{2}{|c|}{ Interaction } & NS & NS & NS & NS & NS & NS & NS & NS & NS & NS & NS & NS \\
\hline
\end{tabular}

Also, it is evident from data illustrated in Table 4 that Giza 178 cultivar had highest agronomic efficiency of nitrogen fertilizer under saline soil compared with Sakha 101 and 102 cultivars and this may be attributed to increases in number of panicles $/ \mathrm{m}^{2}$, number of filled grains/panicle reflected increases in grain yield /ha . Differential behavior of the tested cultivars under saline soil conditions may be attributed to the differences in the level of salt tolerance which depend upon the genetically make up of these cultivars as shown in Table 1. Similar results were also reported by Zeidan et.al. (1980), Rahman (1985), Abd EL-Rahman et al., (1988) and Abed El-Wahab (1998).

\section{Nitrogen sources effects:}

Highly significant differences were detected among the studied nitrogen sources regarding number of panicles $/ \mathrm{m}^{2}, 1000$-grain weight $(\mathrm{g})$,number of filled grains/panicle, grain (in both seasons) and straw (in the second season) yields 
Table 4: Means of grain and straw yields (t/ha), agronomic efficiency of nitrogen fertilizer, sink capacity and sink size as affected by rice cultivars performance and nitrogen sources during both seasons.

\begin{tabular}{|c|c|c|c|c|c|c|c|c|c|c|}
\hline \multirow[t]{2}{*}{ Treatments } & \multicolumn{2}{|c|}{$\begin{array}{l}\text { Grain yield } \\
\text { (t/ha) }\end{array}$} & \multicolumn{2}{|c|}{$\begin{array}{l}\text { Straw yield } \\
\text { (t/ha) }\end{array}$} & \multicolumn{2}{|c|}{$\begin{array}{c}\text { Agronomic } \\
\text { efficiency of } \\
\text { nitrogen } \\
\text { fertilizer } \\
\end{array}$} & \multicolumn{2}{|c|}{$\begin{array}{c}\text { Sink capacity } \\
\text { No. of } \\
\text { grains/m }\end{array}$} & \multicolumn{2}{|c|}{ Sink size $\mathrm{kg} / \mathrm{m}^{2}$} \\
\hline & 2008 & 2009 & 2008 & 2009 & 2008 & 2009 & 2008 & 2009 & 2008 & 2009 \\
\hline \multicolumn{11}{|c|}{ Cultivars: } \\
\hline Giza 178 & 7.407 & 7.200 & 8.207 & 7.869 & $77.1^{\mathrm{n}}$ & 75.0 & 68408 & 62696 & 1.491 & 1.242 \\
\hline Sakha 101 & 5.753 & 5.447 & 7.613 & 7.587 & 59.1 & 56.7 & 48345 & 47295 & 1.301 & 1.280 \\
\hline Sakha 102 & 5.707 & 5.107 & 7.517 & 7.627 & 59.4 & 53.1 & 44060 & 44421 & 1.207 & 1.229 \\
\hline F. test & $* *$ & $* *$ & $* *$ & $* *$ & $* *$ & $* *$ & $* *$ & $* *$ & $* *$ & $* *$ \\
\hline LSD $\mathbf{5 \%}$ & 0.238 & 0.175 & 0.243 & 0.117 & 2.4 & 1.8 & 2149 & 1894 & 0.92 & 0.39 \\
\hline LSD $1 \%$ & 0.347 & 0.255 & 0.353 & 0.171 & 3.6 & 2.6 & 3126 & 2755 & 0.135 & 0.053 \\
\hline \multicolumn{11}{|c|}{ Nitrogen sources } \\
\hline Urea & 6.380 & 6.253 & 7.827 & 7.846 & 66.5 & 65.1 & $|54881|$ & 54881 & 1.363 & 1.371 \\
\hline $\begin{array}{l}\text { Ammonium } \\
\text { sulphate }\end{array}$ & 6.440 & 5.900 & 7.863 & 7.636 & 67.1 & 63.5 & 54888 & 51911 & 1.362 & 1.328 \\
\hline $\begin{array}{l}\text { Ammonium } \\
\text { nitrate }\end{array}$ & 6.047 & 5.600 & 7.647 & 7.600 & 62.9 & 58.3 & 51043 & 48170 & 1.274 & 1.234 \\
\hline F. test & $* *$ & $* *$ & NS & * & $* *$ & $* *$ & $* *$ & $* *$ & $* *$ & $* *$ \\
\hline LSD & 0.231 & 0.184 & - & 0.163 & 2.4 & 1.9 & 1747 & 1656 & 0.057 & 0.063 \\
\hline LSD & 0.336 & 0.269 & - & - & 3.5 & 2.8 & 2543 & 2410 & 0.083 & 0.091 \\
\hline Interaction & NS & NS & NS & NS & NS & NS & NS & NS & NS & NS \\
\hline
\end{tabular}

(t/ha) as showed in Tables 3 and 4. The results indicated that the three nitrogen sources had similar effect on plant height, number of tillers/hill, panicle length and straw yield/ha. Urea produced more number of panicles $/ \mathrm{m}^{2}$, number of filled grains /panicle and grain yield compared to those produced by ammonium sulphate. Moreover, ammonium sulphate produced the heaviest 1000-grain weight (25.76 g) as compared to the other sources as an average of both seasons. The increases in grain yield /ha due to using urea as a source of nitrogen may be attributed to increases in both number of panicles $/ \mathrm{m}^{2}$ and number of grains /panicle. Similar results were also reported by De Datta et al. (1974) and Saares et al. (1983).

Sink capacity and sink size of the three rice cultivars as influenced by different sources of nitrogen fertilizer are presented in Table 2. The results indicated that urea and ammonium sulphate gave higher sink capacity and size than ammonium nitrate. The increases in both sink capacity and size due to using urea and ammonium sulphate as a sources of nitrogen may be due to its effect of 
increases in number of tillers per unit area although did not reach to the significant differences as shown in Table 3. These results are in harmony with those obtained by Rahman (1985) and Abd EL-Rahman et al. (1988).

It is evident from the results are shown in Table 4 that urea or ammonium sulphate gave the highest agronomic efficiency followed by ammonium nitrate that gave the lowest values in this respect. It could be attributed to the decrease in the losses of available nitrogen which comes from ammonium sulphate or urea under salinity condition (De Datta et al., 1974).

\section{Interaction effects:}

There are insignificant effects due to the interaction between rice effected separately.

Conclusively, it could be concluded that for maximizing grain yield of rice per unit area by planting Giza 178 cultivar and using urea or ammonium sulphate as a source of nitrogen under the saline soil at North Delta region.

\section{REFERENCES}

Abd EL-Rahman, A.A.M.; A.T. Badawi and A.E. Draz (1988). Productivity of some rice varieties as influenced by different seedling ages under saline soil condition. Proceeding of $3^{\text {rd }}$ Conference Agron., Alexandria, Egypt, 5-7. Sept., 2: 109-117.

Ade EL-Wahab, A.E. (1998). Physiological behavior of some Egyptian rice cultivars under different nitrogen levels. Egyptian Journal of Applied Science, 13(4): 119- 129.

De Datta, S.K. (1972). A study for salt tolerance of twelve varieties of rice. Current Science, 41:456-457.

De Datta, S.K.; F.A. Saladoga ; W.N. Obcemea and T. Yoshida (1974). Increasing efficiency of fertilizer $\mathrm{N}$ in flooded tropical rice. Page 165288 in the fertilizer association of India. Proceeding of the FAI-FAO Seminar on Optimizing Agriculture Production Under Limited Availability of Fertilizer, New Delhi.

Gomez, K.A. and A.A. Gomez (1984). Statistical Procedures For Agricultural Research. $2^{\text {nd }}$ Ed. Pp. 680. John Willey and Sons, New York, USA. 
Koriem, M.A. ; R.A. Ali; M. Rizk and R.A. Saber (1992). Effect of nitrogen forms, rates and methods of application on yield and yield components of rice cultivated in salt soil affected clay soil. Journal of Agriculture Research, Tanta Univeristy, 18(3): 548 -557.

Kumar, R.J. and P. Kandaswamy (1984). Effect of different sources and levels of $\mathrm{N}$ fertilization on yield of rice variety IR 20. Madras Agriculture Journal., 71(2): 132- 133.

Ling, C. and J.Yang (1986). Studies on grain-leaf ratio of population and cultural approaches of high yield in rice plants. Science of Agriculture Sin., 86(3):1-8, Mass, E.V. and G. J. Hoffman (1977). Crop salt tolerance, current assessment. Journal of Irrigation Drainage Dir., ASCE, 103: 115-134.

Meelu, O.P. ; S. Saygar; M.S. Mashina and R.S. Rekhi (1987). Time and source of nitrogen application in rice and wheat. Journal of Agriculture Science, UK, 109: 387- 391.

Page, A.L.; R.H. Miller and D.R. Keaney (1982): Methods Of Soil Analysis. Part 2. Chemical and Microbiological properties. Amr. Soc. Agron., Madison, Wisconsin, USA.,

Rahman, M.S. (1985). The relation between some growth parameters and yield components of rice as influenced by nitrogen levels and genotypes. Annals of Applied Biology, 107 (2): 325-333.

Saares, S.F. ; F.G. Silva and F.S. Batista (1983). Sources, methods and dates of $\mathrm{N}$ application on the cultivation of irrigated rice in the region of lower San Francisco. Anais, 12 Reuniaoda Cultura do Arroz Irrigao, 113114.(C.F. Computer Search)

Yoshida, S. (1983). Rice In Potential Productivity Of Field Crops Under Different Environments. Eds. W.H. Smith and S. J. Banata, pp: 103-127, IRRI, Los Banos, Philippines.

Zeidan, S.M; A.G. Eraky and A.A.M. Abdel-Rahman(1980). Effect of salinity levels and methods of $\mathrm{N}$ application on yield of some rice cvs. Zagazig Journal of Agriculture Research, 7 (2):219-250. 


\section{سلوك بعض اصناف الارز تحت مصادر مختلفه من التسميد النيتروجينى بالاراضى الملحيه بشمال الألتا}

\section{على السعيد شريف - على عبد الحميل حسان

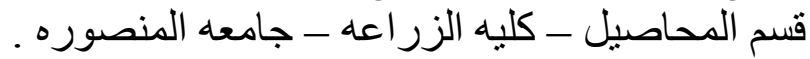 قسم الانتاج النباتي - معهد الكفايه الانتاجيه - جامعه الزقازيه المنيق .}

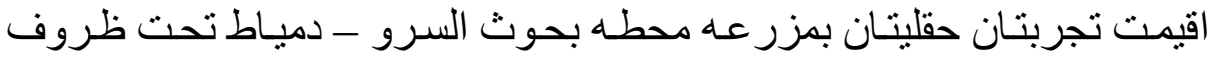

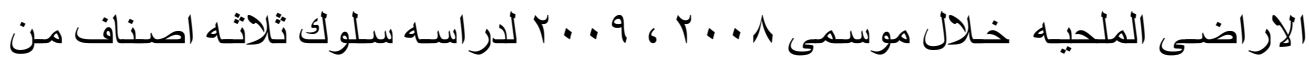

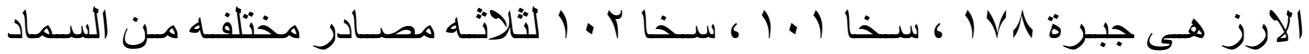

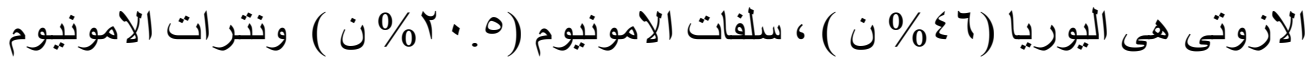



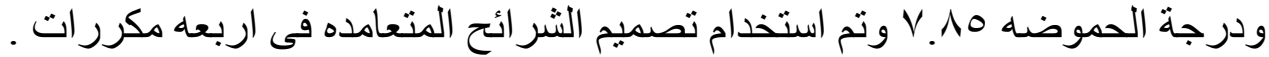

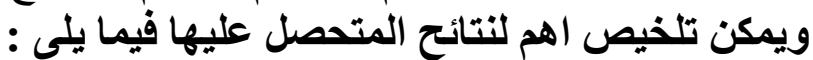

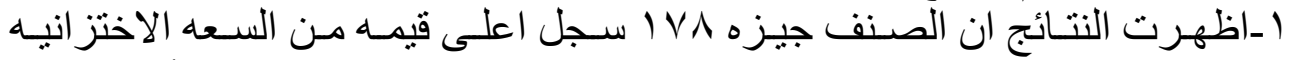
SINK CAPACITY

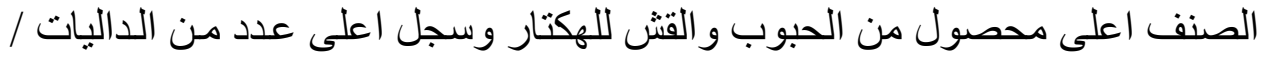

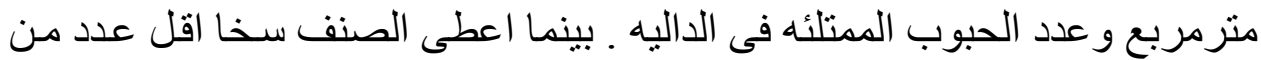

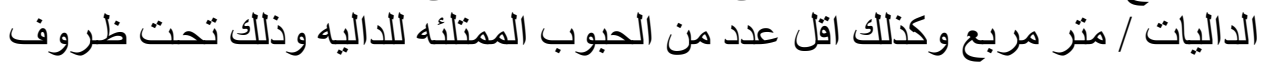

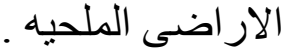

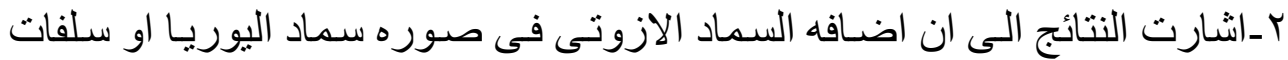



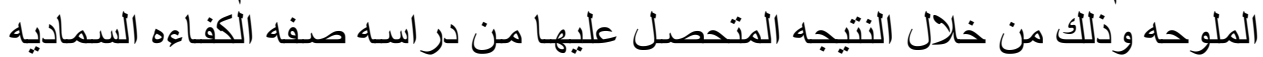

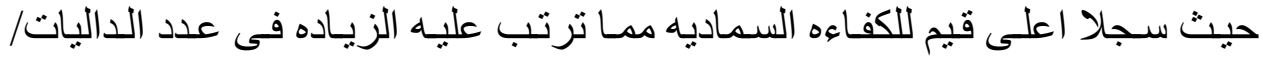

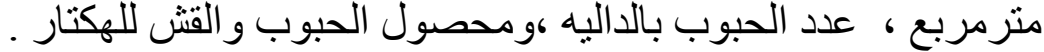



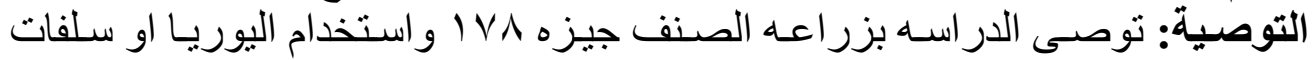

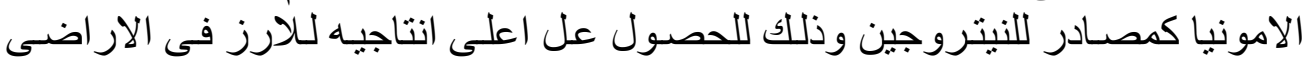

